\title{
Tentative Schedule of ACRL Midwinter Meetings
}

ala Midwinter Meeting

ChICAGo. IllinoIS

JANUARY $19-25,1980$

\section{ACRL BOARD OF DiRECTORS}

First Board Meeting: Monday, January 21, 9:30 a. m. $-12: 30$ p.m.

Second Board Meeting: Wednesday, January 23, 2:00-5:30 p.m.

Budget and Finance Orientation Workshop: Sunday, January 20, 2:00-5:30 p.m.

\section{ACRL Divisional Committees}

Academic/Research Librarian of the Year Award: Monday, January 21, 9:30-11:00 a.m.

Academic Status: Monday, January 21, 9:30 11:00 a.m.; Wednesday, January 23, 9:30-11:00 a.m.

Appointments and Nominations: Tuesday, January $22,8: 00-10: 00$ p.m.*

Audiovisual: Monday, January 21, 9:30-11:00 a.m.

Budget and Finance: Sunday, January 20, 11:30 a.m.-12:30 p.m.; Tuesday, January 22, 8:00 9:00 a.m.

Chapters: Monday, January 21, 8:00-11:00 a.m.

Chapters Council: Sunday, January 20, 5:308:00 p.m. *

Conference Executive Committee-ACRL National Conference, Minneapolis, 1981: Tuesday, January 22, 9:30-11:00 a.m.

Conference Program Planning-New York, 1980: Wednesday, January 23, 9:30-11:00 a.m.

Conference Program Planning-San Francisco, 1981: Sunday, January 20, 11:30 a.m.-12:30 p.m.

Constitution and Bylaws: Tuesday, January 22, 8:00-10:00 p.m.

Continuing Education: Tuesday, January 22, 9:30-11:00 a.m.; Wednesday, January 23, 9:30 a.m.-11:00 a.m.

Copyright: Sunday, January 20, 2:00-4:00 p.m.; Monday, January 21, 11:30 a.m. $-12: 30$ p.m.

Legislation: Monday, January 21, 8:00-9:00 a.m.; Wednesday, January 23, 9:30-11:00 a.m.

Membership: Tuesday, January 22, 9:30 a.m$12: 30$ p.m.; Wednesday, January $23,9: 30$ a. m. $-12: 30$ p.m.

Planning: Monday, January 21, 9:30-11:00 a.m.; Tuesday, January 22, 11:30 a.m. $-12: 30$ p.m.

Publications: Monday, January 21, 8:00-9:00 a. m.; Wednesday, January 23, 8:00-9:00 a.m.
Publications Search Subcommittee for College \& Research Libraries Editor: Sunday, January 20, 8:00-10:00 p.m. *; Monday, January 21, 12:00 2:00 p.m.*; Tuesday, January 22, 8:00-11:00 a. m.*

Standards and Accreditation: Tuesday, January 22, 2:00-4:00 p.m.

Standards and Accreditation, "Standards for College Libraries" Revision Subcommittee: Sunday, January 20, 9:30-11:00 a.m.; Monday, January 21, 9:30-11:00 a.m.; Wednesday, January $23,8: 00-9: 00$ a.m.

Supplemental Funds: Tuesday, January 22, 8:00-9:00 a.m.

\section{ACRL EdTTORIAL BOARDS}

Choice: Monday, January 21, 9:30-11:00 a.m.

College \& Research Libraries: Tuesday, January 22, 4:30-5:30 p.m

College \& Research Libraries News: Tuesday, January 22, 8:00-10:00 p.m.

Nonprint Media Publications: Monday, January 21, 11:30 a.m.-12:30 p.m.; Tuesday, January 22, 11:30 a.m. $-12: 30$ p.m.

Publications in Librarianship: Monday, January 21, 9:30-11:00 a.m., 11:30 a.m. $-12: 30$ p.m.

\section{ACRL Sections}

Anthropology Section

Executive Committee: Tuesday, January 22, 11:30 a.m. $-12: 30$ p.m.

Asian and African Section

Executive Committee: Tuesday, January 22 . 9:30-11:00 a.m.

\section{Art Section}

Executive Committee: Sunday, January 20, 9:30-11:00 a.m.; Tuesday, January 22, 8:0010:00 p.m.

Bibliographic Instruction Section

Executive Committee: Tuesday, January 22, 2:00-4:00 p.m.

Executive Council: Tuesday, January 22, 9:30 a.m. $-12: 30$ p.m.

Conference Program Planning, New York: Sunday, January 20, 11:30 a.m. $-12: 30$ p.m.

Continuing Education: Sunday, January 20, 8:00-9:00 a.m.

Cooperation: Monday, January 21, 9:30 a.m12:30 p.m.

Cooperation-Clearinghouses: Sunday, January 20, 4:30-5:30 p.m.

Education for Bibliographic Instruction: Sun-

${ }^{*}$ Closed meeting. 
day, January 20, 9:30 a.m.-12:30 p.m.

Nominating: Tuesday, January 22, 9:30-11:00 a.m.

Policy and Planning: Monday, January 21, 8:00-11:30 a.m.

Research: Sunday, January 20, 8:00-10:00 p.m.

College Libraries Section

Executive Committee: Monday, January 21, 8:00-9:00 a.m.; Wednesday, January 23, 8:00-9:00 a.m.

Conference Program Planning, New York: Monday, January 21, 9:30-11:00 a.m.; Tuesday, January 22, 9:30-11:00 a.m.

Continuing Education: Monday, January 21, 9:30-11:00 a.m.; Tuesday, January 22, 2:004:00 p.m.

Impact of National Library Policy and National Library Developments (Ad Hoc): Tuesday, January 22, 8:00-9:00 a.m

Membership Participation in the CLS (Ad Hoc): Tuesday, January 22, 8:00-9:00 a.m.

Nominating: Tuesday, January 22, 2:00-4:00 p.m.*

Nonprint Media and the College Library (Ad Hoc): Tuesday, January 22, 8:00-9:00 a.m.

Standards and Guidelines for the College $\mathrm{Li}$ brary (Ad Hoc): Tuesday, January 22, 8:009:00 a.m.
Community and Junior College Libraries Section Executive Committee: Tuesday, January 22, 11:30 a.m.-12:30 p.m.; Wednesday, January 23, 8:00-9:00 a.m.

Bibliography: Monday, January 21, 9:00-11:00 a. $m$.

Communications: Monday, January 21, 2:004:00 p.m.

Instruction and Use: Tuesday, January 22, 4:30-5:30 p.m.

Nominating: Sunday, January 20, 8:00-10:00 p.m."

Planning and Procedures: Tuesday, January 22, 2:00-4:00 p.m.

Education and Behavioral Sciences Section

Bibliographic Instruction for Educators: Tuesday, January $22,9: 30$ a.m. $-12: 30$ p.m.

Curriculum Materials: Saturday, January 19, 2:00-4:00 p. m.

Problems of Access and Control of Education and Materials: Sunday, January 20, 2:00-4:00 p. $m$.

Psychology/Psychiatry (Ad Hoc): Tuesday, January 22, 2:00-4:00 p.m.

Standards for Education Library Services: Tuesday, January 22, 2:00-4:00 p.m.

Law and Political Science Section

Executive Committee: Sunday, January 20, 9:30-11:00 a.m.

*Closed meeting.

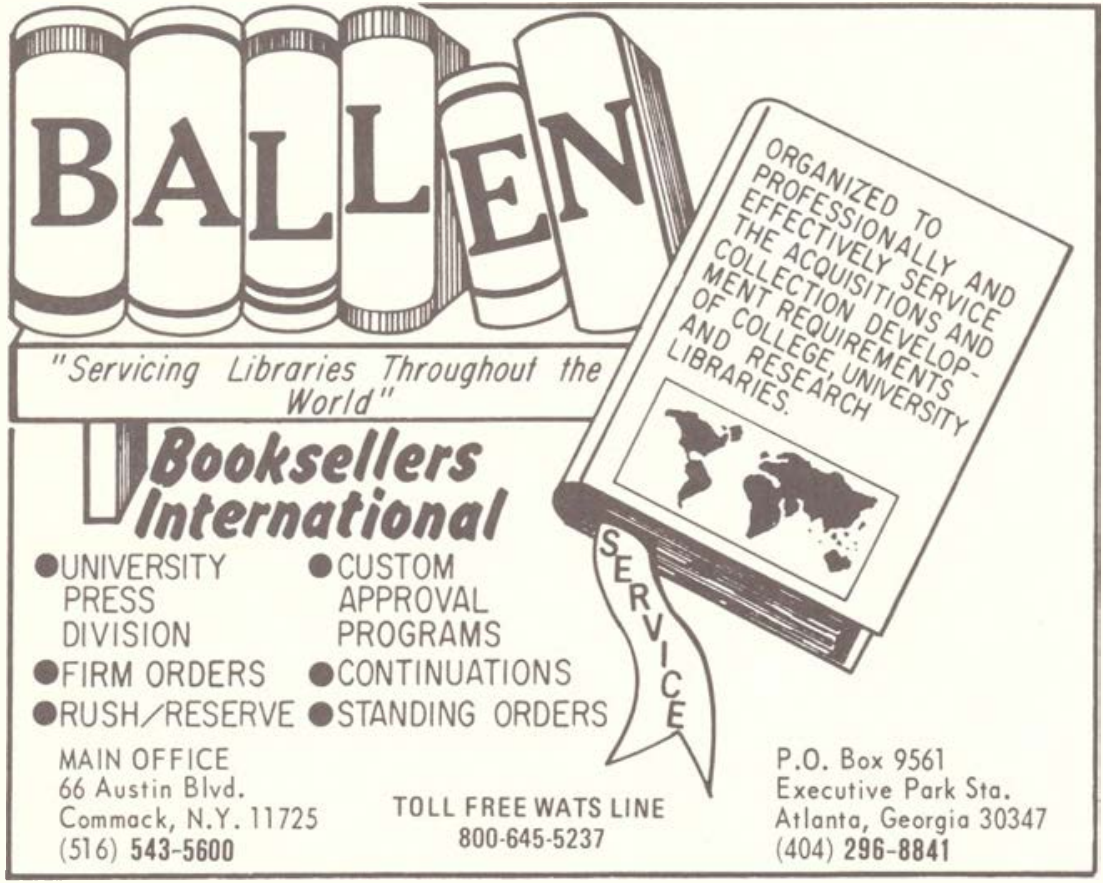


Rare Books and Manuscripts Section

Executive Committee: Sunday, January 20, 9:30-11:00 a.m.; Monday, January 21, 9:30 11:00 a.m.

Continuing Education: Sunday, January 20, 11:30 a.m. $-12: 30$ p.m.

Manuscripts: Sunday, January 20, 8:00-9:00 a.m.

Security: Sunday, January 20, 4:30-5:30 p.m.

Standards: Sunday, January 20, 2:00-4:00 p.m.

Science and Technology Section

Executive Committee: Sunday, January 20, 9:30-11:00 a.m.

Conference Program Planning, New York: Sunday, January 20, 11:30 a.m.-12:30 p.m.

Nominating: Monday, January 21, 9:30-11:00 a. $m$.

University Libraries Section

Steering Committee: Tuesday, January 22, 9:30-11:00 a.m.

Urban University Libraries: Tuesday, January 22, 4:30-5:30 p.m.

Western European Specialists Section

Executive Committee: Monday, January 21, 9:30 a.m. $-12: 30$ p.m.

\section{ACRL}

\section{Discussion Groups}

Alternatives to the Card Catalog: Tuesday, January 22, 9:30-11:00 a.m.

Cinema Librarians: Monday, January 21, 9:30 11:00 a.m.

Librarians of Library Science Collections: Saturday, January 19, 4:30-5:30 p.m.

Personnel Officers of Research Libraries: Monday, January 21, 2:00-4:00 p.m.; Tuesday, January 22, 9:30-1 1:00 a.m.

Staff Development in Academic Research Libraries: Monday, January 21, 9:30-11:00 a.m.; Tuesday, January 22, 8:00-9:00 a.m.; Wednesday, January 23, 8:00-9:00 a.m.

Undergraduate Librarians: Monday, January 21, 9:30-11:00 a.m.

*Closed meeting.

\section{AAUP VICTORY AT NEBRASKA}

The American Association of University Professors won a collective bargaining election at the University of Nebraska at Omaha (UNO) on September 28.

The association's Omaha chapter won by a vote of 216 to 178 the right to represent the UNO faculty and librarians in collective bargaining.

Approximately fourteen librarians were eligible to participate in the vote. Seven librarians were members of AAUP before the election.

\section{WILLIS WRIGHT DIES}

Willis E. Wright, 75, Williams College librarian and former ACRL president, died on October 2 in Portola Valley, California. He had served as librarian at Williams College for twenty-one years and after his retirement had begun a new career as rare books cataloger at Stanford University Libraries.

Bill was an extraordinary individual and a remarkable addition to our company at Stanford during the past ten years. He started work in September 1969 as a

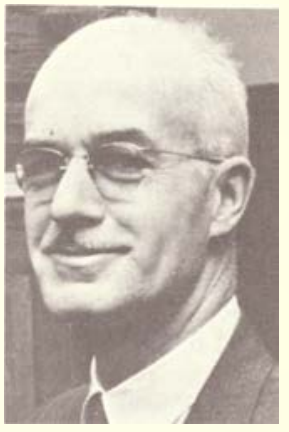
cataloger of sixteenth-century imprints, American almanacs, and also early American imprints in the Department of Special Collections. He reduced his schedule to part-time in 1974 but worked until just the last few weeks before his death on cataloging of the most difficult imprints, both monograph and serials and in a wide range of classical and modern languages. During the entire year 1973-74, he was chief of the Department of Special Collections.

A Phi Beta Kappa, Wright was a graduate of Williams College, majoring in philosophy, and received his master's degree from Williams in philosophy and Greek. He was a cataloger and chief cataloger at the New York Public Library from 1927 to 1945, librarian of the Army Medical Library during 1945-46, and librarian for Williams from 1947 to 1968 , when he ostensibly retired. Bill was president of the Association of College and Research Libraries in 1949-50, president of the former Cataloging and Classification Association, and recipient of the Melvil Dewey Medal in 1957. In addition, from 1954 to 1967, he was chair of the Catalog Code Revision Committee and chair from 1947 to 1967 of the Union List of Serials Joint Committee. One of his various publications was a 1948 translation of the Vatican cataloging rules.

Perhaps Bill's greatest achievement in special collections was clearing the backlog of uncataloged items. In a letter of May 28, 1970, Bill says, "I love to put through books that have been sitting around for seventy-five years or so-it gives an impression of progress." Bill also had the knack of quickly identifying books that lacked title pages or incipits. Bill was a remarkable friend and colleague.-David C. Weber.

Editor's Note: This tribute is reprinted from the Stanford Library Bulletin, October 12, 1979. 